\title{
Contents, Vol. 25, 1974
}

Caldwell, T. and Solomon, S.: Changes in Oxygen Consumption of Kidney during Maturation 1

Kerr, G. R. and Helmuth, A. C.: Growth and Development of the Fetal Rhesus

Monkey. V. Fatty Acids of Phospholipids in Fetal Lung

Chow, A.Y.K. and Ecobichon, D.J.: Perinatal Development of Cavian Plasma,

Hepatic and Renal Esterases 23

Walker, D.: Functional Development of the Autonomic Innervation of the Human

Fetal Heart 31

Morriss, F.H., jr.; Makowski, E.L.; Meschia, G, and Battaglia, F.C.: The

Glucose/Oxygen Quotient of the Term Human Fetus 44

Marthens, E. van; Grauel, L., and Zamenhof, S.: Enhancement of Prenatal

Development in the Rat by Operative Restriction of Litter Size 53

Schulman, J.D.; Mann, L.I.; Doores, L.; Duchin, S.; Halverstam, J., and

Mastrantonio, J.: Amino Acid Metabolism by the Fetal Brain during Normal

and Hypoglycemic Conditions

57

McGowan, A.; Jordan, M., and MacGregor, J.: Skinfold Thickness in Neonates 66 Novak, M.;

Penn-Walker, D.; Hahn, P., and Monkus, E. F.: Effect of Carnitine

on Lipolysis in Subcutaneous Adipose Tissue of Newborns 85

Novak, M.; Penn-Walker, D., and Monkus, E.F.: Oxidation of Fatty Acids by

Mitochondria Obtained from Newborn Subcutaneous (White) Adipose Tissue. 95 Gennser, G. and Lundquist, I.: Acid Amyloglucosidase in Human Fetal Liver

during Acute Asphyxia 108

Dickerson, J. W.T. and Pao, S.-K.: Effect of Pre- and Post-Natal Maternal Protein

Deficiency on Free Amino Acids and Amines of Rat Brain 114

Stewart, R.J.C.; Merat, A., and Dickerson, J.W.T.: Effect of a Low Protein

Diet in Mother Rats on the Structure of the Brains of the Offspring 125

Smart, J.L.; Adlard, B.P.F., and Dobbing, J.: Further Studies of Body Growth and Brain Development in 'Small-for-Dates' Rats 135

Dhindsa, D.S. and Metcalfe, J.: Unilateral Ovariectomy: Effect on Litter Size and Uterine Vessels in Mice 151

Merat, A. and Dickerson, J. W. T.: The Effect of the Severity and Timing of

Malnutrition on Brain Gangliosides in the Rat 158

Fiser, R.H., jr.; Phelps, D.; Williams, P.; Sperling, M.A.; Oh, W., and Fisher, D. A.: Alanine Stimulation of the Pancreatic $\alpha$ - and $\beta$-Cell in the Neonatal Lamb 171 CzajkaNarins, D.M. and Hirsch, J.: Supplementary Feeding during the Preweaning Period. Effect on Carcass Composition and Adipose Tissue Cellularity of the Rat 176

Yao, A. C. and Lind, J.: Blood Flow in the Umbilical Vessels during the Third Stage of Labor 186 
IV

Contents

Cabau, N.; Levy, F.M.; Zivy, D.; Barrier, J., and Roux, F.: Evolution of Titre of Serum IgG in Newborn 194

Baum, J.D.; Hughes, E.A., and Harris, D.A.: Neonatal Hair as a Record of Intra-Uterine Nutrition 208

Sommer, A.; Bradel, E.J., and Hamoudi, A.B.: The Cerebro-Hepato-Renal

Syndrome (Zellweger's Syndrome) 219

Svenningsen, N. W. and Aronson, A. S.: Postnatal Development of Renal Con centration Capacity as Estimated by DDAVP-Test in Normal and Asphyxiated Neonates 230

Alexander, D. P.; Bashore, R. A.; Britton, H. G. , and Forsling, M. L.: Maternal and Fetal Arginine Vasopressin in the Chronically Catheterised Sheep 242

Reddy, G.D.; Gootman, N.; Buckley, N.M.; Gootman, P.M., and Crane, L.:

Regional Blood Flow Changes in Neonatal Pigs in Response to Hypercapnia, Hemorrhage and Sciatic Nerve Stimulation 249

Ravazzolo, R.: Effect of Inorganic Phosphate on 2,3-DPG Levels of Fetal and Adult Red Cells 263

Fenner, A.; Lange, G.-U.; Moenkemeier, D., and Ohlenroth, G.: Estriol

Excretion in the First-Voided Urine of Male Newborns. Relationship with Birth Weight and Gestational Age in Healthy Infants and in those Affected by the Respiratory Distress Syndrome 267

Zachman, R. D.: Alternate Phototherapy in Neonatal Hyperbilirubinemia 283 Parkinson, C.E.; Harvey, D., and Talbert, D.: Surface Properties of Amniotic Fluid Bubbles 289

Wong, P.W.K. and Pildes, R.S.: Plasma Amino Acids in Low-Birth-Weight Infants Treated with Intravenous Amino Acid Infusion 300

Stanton, H.C. and Mueller, R.L.: Epinephrine-Induced Hyperglycemia and Glycogenolysis in Fed and Fasted Neonatal Swine 307

Hoff, K.M.; Baker, P.C., and Buda, R.E.: Tryptophan-5-Hydroxylase Matura

tion in Regions of the Mouse Brain 320

Solomon, S.: Maximal Gradients of $\mathrm{Na}$ and $\mathrm{K}$ across Proximal Tubules of Kidneys of Immature Rats 327

Solomon, S.: Absolute Rates of Sodium and Potassium Reabsorption by Proximal Tubule of Immature Rats $\quad 340$

Morgan, A.J. and Bellamy, D.: Changes in the Mineral Composition of Rat

Femur during Neonatal Growth in Relation to Calcification of Aorta 352

Gross, I. and Warshaw, J.B.: Fatty Acid Synthesis in Developing Brain. Acetyl-

CoA Carboxylase Activity 365

Author Index 376

Subject Index 377 